\title{
Compost of poultry manure and olive mill wastes as an alternative fertilizer
}

\author{
Salma Hachicha, Mohamed Chtourou, Khaled Medhioub, Emna AmmaR* \\ UR Étude et Gestion des Environnements Urbains et Côtiers, LARSEN, École Nationale d'Ingénieurs de Sfax, BP W, 3038 Sfax, Tunisia
}

(Accepted 23 March 2006)

\begin{abstract}
We studied a compost made of poultry manure, olive mill wastes and mineral-rich wastewater, as an alternative fertiliser. The composts were of high quality, characterized by high levels of nutrients, a relatively low $\mathrm{C} / \mathrm{N}$ ratio of $15-17$ and a fertilizing value similar to that of conventional cattle manure, however without phytotoxicity. Field experiments showed an increase in potato production of 31.5-35.5 t/ha, compared to $30.5 \mathrm{t} / \mathrm{ha}$ using cattle manure. The use of olive mill wastewater did not have any negative impact on soil $\mathrm{pH}$, electrical conductivity and phenols. The compost made of poultry manure and olive mill by products appears therefore as a promising ecological alternative to classical fertilizers.
\end{abstract}

poultry manure / olive mill cake / olive mill wastewater / composting / agronomic valorisation of by-products / agro-food industries

\section{INTRODUCTION}

The intensification of agro-food activities such as the industrialization of poultry meat and the extraction of olive oil generates a huge quantity of organic by-products, which are causing serious environmental problems to solve. Indeed, on the one hand, poultry meat has become the main source of proteins in many developing countries like Tunisia. The industrialization of this activity is generating huge amounts of poultry manure. For meat chicken, the average animal produces $2 \mathrm{~kg}$ in 7 or 8 weeks, while the yearly output of a layer or genitor is estimated to $65 \mathrm{~kg}$ (Bouzouaia and Rannen, 2003). This byproduct of this agro-industry is well known for its negative impact on the environment. It has some anaesthetic effects and a high concentration of ammonia which when released in the atmosphere spreads a very bad smell (Georgakakis, 2000).

On the other hand, the extraction of olive oil, a very important product to populations around the Mediterranean Sea, causes another threat to the environment. Indeed, despite the benefits of olive oil as a source of fat in many Mediterranean diets and a main activity in the economic development of many southern Mediterranean countries, its extraction releases huge amounts of solid/liquid waste matter regardless of the processes used. A semi-solid residue known as olive mill cake has a typical moisture of $40 \%$ and a liquid-phase commonly known as olive mill waste. This black effluent contains a proportion of fine solid matter including remaining particles of crushed olive stones, flesh and skins, sugars, nitrogen-containing compounds, volatile acid, polyalcohol, pectin, fats, salts and polyphenols. The volume of olive mill wastewater may vary from 50 to $150 \mathrm{~L}$ for $100 \mathrm{~kg}$ of the processed olives depending on the processing system (Sierra et al., 2001; Parades et al., 2001; Chtourou et al., 2004).

In Tunisia, the first by-product of the agro industry amounts to approximately 650000 tons of poultry manure every year while the second rejects 500000 tons of olive mill wastewater yearly (Bessadok, 2001; GIPA, 2004). Both pollutants represent serious environmental problems that need to be handled urgently. Several works have suggested using poultry manure as a fertilizer to improve crop production in organic farming. However, excessive manure applications are plant toxic due to high salt content and accumulation in plants of trace metal, which may pose a health risk and lead to ground and surface water pollution (Nicholson et al., 1996; Wong et al., 1999). Moreover, the addition of bulking agent during cattle and pig manure composting was demonstrated to have a positive effect on enzyme activities and the choice of bulking agent strongly affected the potential capacity and properties for mineralization of organic phosphorus in manure composts (Vuorinen, 2000).

Olive mill wastewater was also suggested as a soil fertilizer (Tomati et al., 1996; Ammar and Ben Rouina, 1999; Houot, 2000; Zenjari and Nejmeddine, 2001). Nevertheless, recent results revealed that this solution has some drawbacks such as infiltration of phenolic compounds and inhibition of microflora (Shabou et al., 2005). Hence, composting was proposed as a better solution for both pollutants but separately. However, to our knowledge, there is scarce information on composting poultry manure by using olive mill wastewater.

This work describes the evolution of the composting parameters of mixtures of poultry manure, an industrial agro food

\footnotetext{
* Corresponding author: ammarenis@yahoo.fr
} 
waste and exhausted olive mill cake, a by-product from soap factory, used as bulking agent and olive mill wastewater as a humidifier. Two aerated windrows were investigated. Potato of the variety Spunta was cultivated in soils amended with the prepared composts. The impact of the by-products used during all the process was assessed by the determination of soil physicochemical properties.

\section{MATERIALS AND METHODS}

In this work, compost was achieved by mixing poultry manure and exhausted olive mill cake from soap factory as bulking agent and olive mill wastewater as a humidifier. Windrows including defined proportions of poultry manure and exhausted olive mill cake were well mixed and aerated by mechanical turning to keep the moisture range of 45 to $60 \%$. During the biological process, physico chemical properties were checked and when stabilised, the agronomic properties of both obtained composts were tested on potato crop in vivo: Spunta species (Fig. 1). The impact of intrinsic properties of olive mill wastewater used during composting was assessed by soil physico-chemical determination.

\subsection{Raw materials}

Two raw materials were used in the composting process.

The first raw material poultry manure was collected from an industrialized farm in the area of Sfax, Tunisia. It was characterized by high $\mathrm{pH}$, a high total organic carbon (20\% d.w.), an ash content of $60 \%$ of d.w. and a low $\mathrm{C} / \mathrm{N}$ ratio. The second, exhausted olive mill cake, obtained from a soap factory in the same area, had a low $\mathrm{pH}$, high $\mathrm{C} / \mathrm{N}$ ratio and relatively low minerals (Tab. I). These raw materials were mixed in two windrows (WI and WII) of $8000 \mathrm{~kg}$ each, having the following composition:

- Windrow I: $75 \%$ Poultry manure $+25 \%$ Exhausted olive mill cake;

- Windrow II: $25 \%$ Poultry manure $+75 \%$ Exhausted olive mill cake.

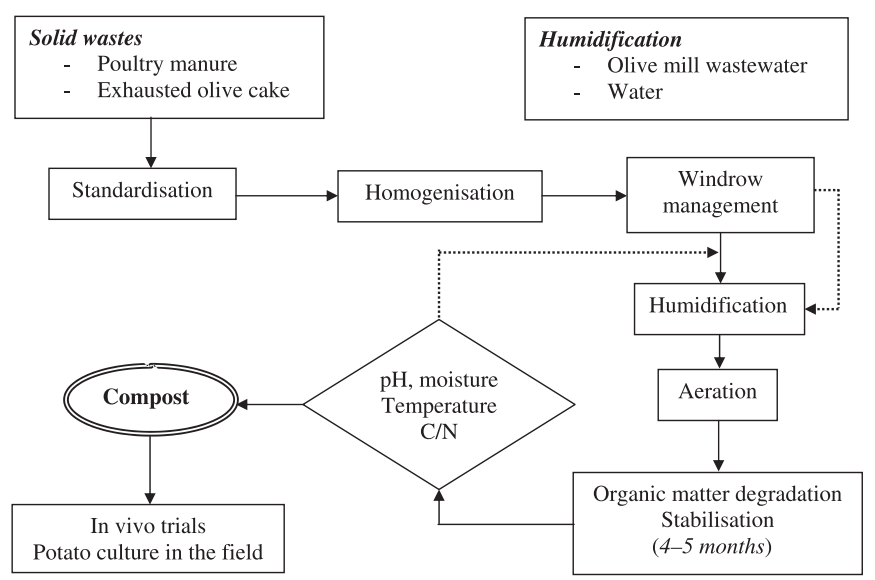

Figure 1. Experimental design and process controle. C: carbon content; $\mathrm{N}$ : total nitrogen content.
Table I. Physico-chemical characteristics of poultry manure and exhausted olive cake used for composting. PM: Poultry manure; EOC: Exhausted olive mill cake; OMW: Olive mill wastewater; TOC: Total organic carbon; TKN: Total kjeldahl nitrogen; d.w.: Dry weight.

\begin{tabular}{lccccc}
\hline Parameters & $\mathrm{pH}$ & \multicolumn{1}{c}{ Moisture (\%) } & TOC (\% d.w.) & TKN (\% d.w.) & $\mathrm{C} / \mathrm{N}$ \\
\hline PM & 9.45 & 45.50 & 20.17 & 1.72 & 11.73 \\
EOC & 5.85 & 19.65 & 42.00 & 1.05 & 39.14 \\
OMW & 5.29 & 90.00 & 42.97 & 0.60 & 71.20 \\
\hline
\end{tabular}

Both windrows were humidified with olive mill wastewater which had an acidic $\mathrm{pH}(\approx 5.3)$, high chemical oxygen demand expressing the carbon content (COD: $178 \mathrm{~g} / \mathrm{L}$ ) and low dry matter content (10\%), its $\mathrm{C} / \mathrm{N}$ ration was 71 and it contained relatively important concentrations of phosphorus and potassium, respectively 3.10 and $1.23 \%$ expressed on dry matter basis. The olive mill wastewater had also high contents in phosphorous (259.72 ppm), potassium (91.70 ppm), magnesium (298.5 ppm) and sodium (280.4 ppm); the rate of nitrogen over phosphorous was equal to 2.3 .

\subsection{Composting process}

During the composting process, moisture was maintained around $50 \%(\mathrm{w} / \mathrm{w})$. Both windrows were turned once every 3 to 4 days during the first two months and once a month for the remaining period of composting. Temperatures were measured on a daily basis at different positions in the core of the windrow and the average of all the measurements was recorded.

\subsection{Physico-chemical and microbiological analyses}

\subsubsection{Physico-chemical determinations}

Samples were taken at turning and consisted of a homogenous mixture of 3 sub samples taken at 3 different depths of the windrow. The following compost properties were analysed: water content was determined by drying at $105^{\circ} \mathrm{C}$ for $24 \mathrm{~h}$. The $\mathrm{pH}$ and electrical conductivity were determined in a solution made by $20 \mathrm{~g}$ of the sample in $100 \mathrm{~mL}$ of distillated water. Ignition of dry matter at $550^{\circ} \mathrm{C}$ in a muffle furnace for $4 \mathrm{~h}$ provided the total organic matter determination.

Total organic carbon (TOC) was determined by dichromate oxidation. Total nitrogen was determined by Kjeldahl method. Extractible $\mathrm{NO}_{3}-\mathrm{N}$ in composts was determined by shaking a sample of $2.5 \mathrm{~g}$ (as a dry substance) in $50 \mathrm{~mL}$ of water for $2 \mathrm{~h}$. The concentration of $\mathrm{NO}_{3}-\mathrm{N}$ was analysed by ionic chromatography. Macro and micro elements were first extracted by heating $2.0 \mathrm{~g}$ of compost with $\mathrm{HNO}_{3}$ and $\mathrm{HCl}$, then the filtrate was analysed by atomic absorption spectrophotometry. The analyses for the characterization of raw materials were performed on five samples and the mean of the results was reported with the statistical analysis expressing the incertitude using ANOVAR software.

\subsubsection{Microbiological analyses}

A microbiological analysis was held at the end of the biological process to ensure of the hygienic aspect of the prepared 
composts. A compost sample of $10 \mathrm{~g}$ was suspended in $90 \mathrm{~mL}$ of a sterile peptone water solution and stirred at $150 \mathrm{rpm}$ for $10 \mathrm{~min}$ at $28^{\circ} \mathrm{C}$. The suspension was used for microbial count by cell enumeration assessed by the determination of the number of colony forming units (cfu), according to ISO 7218 (1985). Serial decimal dilutions of each suspension $\left(10^{-1}\right.$ to $10^{-5}$ ) were plated in triplicate on different agar media: Plate Count Agar (PCA, Pronadisa, Madrid, Spain), for the total aerobic mesophilic and thermophilic flora incubated respectively at $30^{\circ} \mathrm{C}$ and $55^{\circ} \mathrm{C}$ for $72 \mathrm{~h}$, brilliant green bile broth (Bio-Rad, Marnes-la-Coquette, France) using most probable number technique for coliform flora (ISO 4831, 1987), trypticase sulphite with neomycin and polymixine agar (TSN, Bio-Rad, Marnes-la-Coquette, France) for anaerobic sulfito-reducing flora (NF XPV 08-061) and oxytetracycline glucose agar (OGA, Pronadisa, Madrid, Spain) for yeasts and fungi enumeration (NF V08-059, 1995).

\subsection{Assessment of compost phytoxicity}

For the evaluation of the compost toxicity, a semi-early variety of Spunta (Solanum tuberosum L.) was used in different plots of $500 \mathrm{~m}^{2}$ each, fertilized with the prepared composts applied at a rate of 30 tons/hectare. Four plots were amended respectively with compost I $\left(\mathrm{P}_{\mathrm{PM}}\right)$, compost II $\left(\mathrm{P}_{\mathrm{EOC}}\right)$, a mix of $75 \%$ compost $\mathrm{I}$ and $25 \%$ of cattle manure $\left(\mathrm{P}_{\operatorname{mix}} \mathrm{I}\right)$, another mix with $75 \%$ compost II with $25 \%$ of cattle manure $\left(\mathrm{P}_{\text {mix II }}\right)$ and a control plot was fertilized with only conventional cattle manure $\left(\mathrm{P}_{\mathrm{C}}\right)$. Then, potatoes were planted in these plots. The assessment of the composts agronomic effects were based first on the plant growth measurements (in height) throughout the growing season established according to the mean of one hundred plants, and second on the determination of the potato production harvested at the end of the crop cycle.

\subsection{Effects of compost watered with olive mill wastewater on soil characteristics}

The impact of olive mill wastewater used during composting on soil properties was assessed by physico-chemical analysis of soil sampled at three depths: $0.15 ; 0.30$ and $0.50 \mathrm{~m}$. pH, electrical conductivity and phenol concentration were determined just after harvesting potatoes.

\section{RESULTS AND DISCUSSION}

\subsection{Characterization of composting parameters}

\subsubsection{Temperature evolution}

The temperature increased significantly over time in the two windrows. After around 10 days, the temperature rose to above $45^{\circ} \mathrm{C}$ and remained approximately at $50^{\circ} \mathrm{C}$ for 10 days. Then, it increased to reach 60 and $63{ }^{\circ} \mathrm{C}$ respectively in windrow I and II. Finally, it dropped after 40 days and stabilized at above $40{ }^{\circ} \mathrm{C}$. This stabilization occurred around at least 100 days of composting (Fig. 2).

This evolution of temperature revealed a usual thermal effect accompanying organic matter biodegradation as was explained

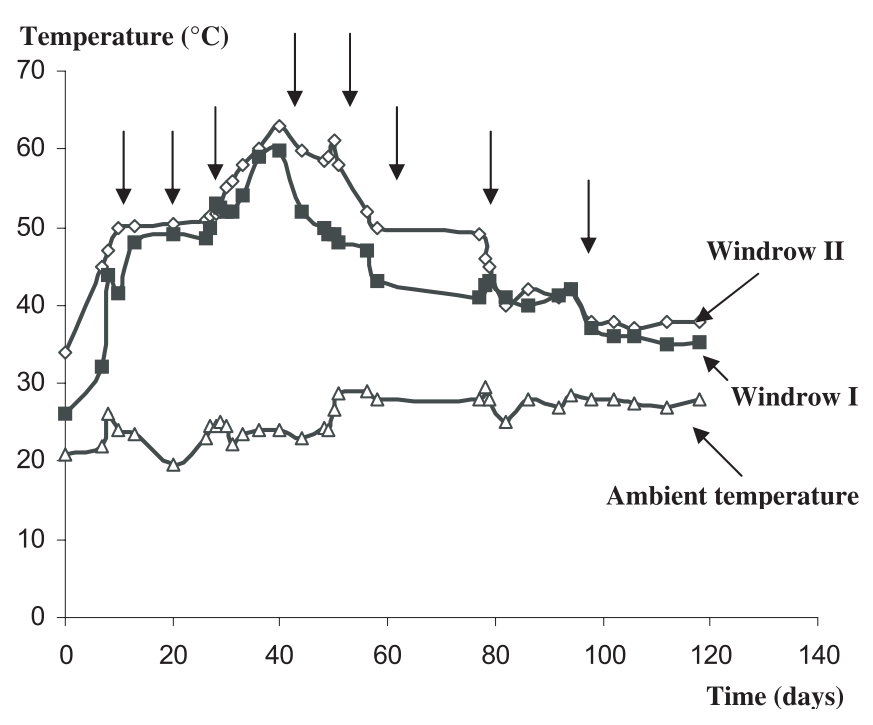

Figure 2. Temperature evolution during composting mixtures of poultry manure and exhausted olive cake. Windrow I: $75 \%$ poultry manure and $25 \%$ exhausted olive cake; windrow II: $25 \%$ poultry manure and $75 \%$ exhausted olive cake. Turnings are indicated by the arrows.

by Mustin (1987). A short mesophilic phase was followed by a relatively long thermophilic phase indicating the quick establishment of microbial activities in the composting windrows. The microorganisms consumed the soluble organic matter and ambient nutrients and then underwent aerobic degradation to generate heat, biomass and carbon dioxides. The short-term drop in temperature was due to the cooling effect caused by the mechanical turning of the piles used for the aeration.

The addition of olive mill wastewater while turning the windrows provided the composting medium with organic matter, which enhanced temperature increase. The windrows entered the cooling phase on about day 40 with a sharp drop in temperature. There was no significant difference in the maximum temperature and the length of thermophilic phase between windrows I and II. This is in line with findings related to cocomposting pig manure with leaves (Huang et al., 2001).

\subsubsection{Organic matter degradation}

Poultry manure and exhausted olive mill cake showed a high organic matter content. But since exhausted olive mill cake is deficient in nitrogen, poultry manure supplemented very well olive mill wastewater by adding the needed nitrogen and minerals. Table II shows changes in the chemical composition of the windrows (I and II) during composting. About $15 \%$ of organic matter content in the respective windrow I and windrow II were lost with the composting time. The important initial rate of poultry manure in windrow I included easily decomposable compounds (organic carbon and nitrogen), which should account for a relatively higher degree of organic matter loss in windrow I as was shown in previous works (Eklind and Kirchmann, 2000). 
Table II. Changes in the chemical composition of the windrows prepared during composting mixtures of poultry manure and exhausted olive cake (Windrow I: $75 \%$ poultry manure and $25 \%$ exhausted olive cake; windrow II: $25 \%$ poultry manure and $75 \%$ exhausted olive cake). OM: Organic matter; TOC: Total organic carbon.

\begin{tabular}{|c|c|c|c|c|c|c|}
\hline \multirow[t]{2}{*}{ Parameters } & \multicolumn{6}{|c|}{ Composting time (days) } \\
\hline & 0 & 9 & 44 & 54 & 87 & 125 \\
\hline \multicolumn{7}{|l|}{ Windrow I } \\
\hline $\mathrm{pH}$ & 9.23 & 8.29 & 9.26 & 8.95 & 9.40 & 8.96 \\
\hline $\mathrm{OM}(\%)$ & 61.70 & 60.60 & 58.10 & 56.70 & 55.00 & 53.4 \\
\hline TOC (\%) & 29.00 & 25.75 & 28.42 & 26.20 & 24.115 & 21.30 \\
\hline Total nitrogen $(\%)$ & 1.34 & 1.22 & 1.25 & 1.29 & 1.37 & 1.40 \\
\hline \multicolumn{7}{|l|}{ Windrow II } \\
\hline $\mathrm{pH}$ & 7.59 & 7.68 & 8.54 & 8.34 & 8.64 & 8.25 \\
\hline $\mathrm{OM}(\%)$ & 64.85 & 64.10 & 63.50 & 61.70 & 60.90 & 58.5 \\
\hline TOC (\%) & 36.70 & 37.01 & 31.38 & 27.44 & 25.26 & 23.43 \\
\hline Total nitrogen $(\%)$ & 1.35 & 1.31 & 1.19 & 1.19 & 1.11 & 1.39 \\
\hline
\end{tabular}

The kinetic model of organic matter biodegradation was slightly different in the two experimented windrows. It is expressed as:

Organic matter $(\%)=-0.070 \mathrm{t}+61.769$ in windrow $\mathrm{I} ; \mathrm{R}^{2}=0.94$

Organic matter $(\%)=-0.048 \mathrm{t}+64.679$ in windrow II; $\mathrm{R}^{2}=0.99$.

The mathematical models varied according to the windrow composition, the availability of nutrients and particle size of the components related to the nature of organic matter being composted. Windrow I seemed to be more easily biodegraded, compared to windrow II.

In spite of differences in kinetic evolution, at the end of composting process, the loss percentage of organic matter was almost equal to $13 \%$ in both experimented windrows. However, the total organic carbon losses were equal to $26 \%$ and $36 \%$, respectively in windrows I and II. These differences would be related to their own specific compositions.

\subsubsection{C/N patterns}

The evolution of $\mathrm{C} / \mathrm{N}$ ratio in each windrow showed a progressive decline in function of time (Fig. 3). It could be noted that $\mathrm{C} / \mathrm{N}$ pattern in windrow I characterized by $75 \%$ poultry manure was lower than that in windrow II. The difference in behaviour was reduced from the 50th day of composting. Indeed, poultry manure of a high nitrogen content lead to a loss of this element in the form of ammoniacal nitrogen and consequently a slow reduction in $\mathrm{C} / \mathrm{N}$ ratio occurred (Fig. 3 ). It could be noted that total nitrogen content of windrow I increased slightly after around 50 days of composting. It increased from $1.2 \%$ to $1.4 \%$. This may be due to the loss of dry mass in terms of carbon dioxide and loss of water by evaporation during the mineralization of organic matter (Mustin, 1987; Fang et al., 1999; Huang et al., 2001). Nitrogen fixing bacteria may also contribute to the increase in total nitrogen in the later stage of composting (Mustin, 1987).

The changes in concentrations of total nitrogen followed a typical trend for the nutrient during aerobic composting (Tab. II). In the first 9 days of composting, nitrogen content of



Figure 3. $\mathrm{C} / \mathrm{N}$ ratio decrease during composting of mixtures of poultry manure and exhausted olive cake. Windrow I: $75 \%$ poultry manure and $25 \%$ exhausted olive cake; windrow II: $25 \%$ poultry manure and $75 \%$ exhausted olive cake.

the two windrows decreased due to ammonification as well as mineralization of organic nitrogen compounds; ammonia contents of the composting may have decreased through volatilisation loss and microbial immobilization. The absence of a decrease in ammonia nitrogen indicated that composting and maturation processes were achieved. Indeed, as Mustin (1987) and Huang et al. (2001) observed, compost with a maximum ammonia content inferior to $400 \mathrm{mg} / \mathrm{kg}$ can be considered as mature compost.

In line with Huang et al. (2001), it was found that nitrate content of the two windrows remained at a low level $(<35 \mathrm{mg} / \mathrm{kg})$. This showed that little nitrification occurred under thermophilic conditions, which inhibited the activity and growth of nitrifying bacteria. Furthermore, at low concentrations, no significant difference of nitrate content was noted between the two windrows throughout the composting process. 


\subsection{Effect of compost sprayed with olive mill waste water}

\subsection{1. $p H$ variation}

The $\mathrm{pH}$ progress of the two windrows differed slightly (Tab. II). Although three phases could be noted during composting in windrow I, and because of the predominance of poultry manure in its initial composition, the $\mathrm{pH}$ variations were more intensive. Indeed, the $\mathrm{pH}$ initially exceeding 9 , dropped during the first nine days. The intensive microbial activity and organic matter degradation led to the formation of carbon dioxide and organic acids. Then $\mathrm{pH}$ increased with bacterial hydrolysis of proteins. Ammonia, as a consequence of organic nitrogen ammonification, was produced. The solubilization of the ammonia led to the formation of ammonium and an increase in the $\mathrm{pH}$ values in the composting mixtures where the initial values rose from 8.2 to 9.3 and from 7.7 to 8.5 respectively in windrows I and II. At the same time, the temperature inside the windrows started to rise improving thermophilic microbial activity (Fig. 2).

However, in windrow II which had only $25 \%$ of poultry manure in its initial composition, ammonium formation was weak due to the slow rate of organic matter degradation (Fig. 3). But after the thermophilic stage, the $\mathrm{pH}$ dropped in the two windrows with a lesser degree in windrow II. This would be related to a relatively high proportion of exhausted olive mill cake rich in carbon and with low $\mathrm{N}$ content.

After 100 days of composting, the decrease in $\mathrm{pH}$ was likely caused by the volatilisation loss of ammonia and the increase in $\mathrm{H}^{+}$from the nitrification process as was shown by Huang et al. (2001). Also, the microbial decomposition of organic matter and the production of organic and inorganic acids would be responsible for the $\mathrm{pH}$ decrease as found in previous work (Mustin, 1987). It should be noticed that in spite of the acidic $\mathrm{pH}$ of olive mill wastewater used during humidification, this effluent did not have any negative impact on the composting mixture $\mathrm{pH}$.

\subsubsection{Soluble phenolic compounds}

The main problem generated by the spread of olive mill wastewater on soils was attributed to their phenolic content (Shabou et al., 2005). As it is well known, such phenolic compounds are recalcitrant and may contaminate soils and groundwater. However, despite their continuous use for the humidification of the windrows during all the process, the determination of soluble phenols contents in the windrows at initial time and after composting showed an important decrease of phenols in the two windrows I and II. This was respectively of $37 \%$ and $46 \%$, expressed on a dry matter basis while the initial values were respectively $0.43 \%$ and $0.52 \%$ (d.w.).

This may be due to the intensive microbial activity. Indeed, previous works isolate bacteria, yeast and fungi and demonstrate their ability to use phenolic compounds of olive mill wastewater (Chtourou et al., 2004). The relatively low concentration of phenolic compounds remaining in the compost would be degraded by telluric flora when the fertilizer is incorporated in the soil for amendment.
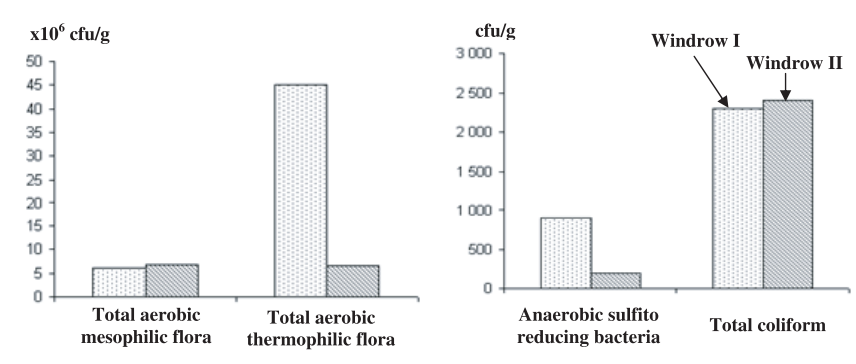

Figure 4. Microbial content of the mature composted windrows (cfu/g). Windrow I: $75 \%$ poultry manure and $25 \%$ exhausted olive cake; windrow II: $25 \%$ poultry manure and $75 \%$ exhausted olive cake.

\subsubsection{Microbial flora of composts}

Microbiological analysis of the mature composts showed equal concentrations of total mesophilic flora, fecal coliforms, anaerobic sulfito-reducing bacteria and yeast, and moulds. However, thermophilic flora was more important in windrow I. Pathogenic bacteria such as Staphylococcus and Salmonella were absent in the two windrows (Fig. 4). The number and types of microbial pathogens initially present in the wastes varied with animal species, geographic location of the form, and the physico-chemical composition of the manure (Bicùdo and Goyal, 2003).

Many pathogenic bacteria to humans carried via animals in poultry are found at high concentration in the manure. Salmonella are facultative anaerobic bacteria, which can proliferate in places with little or no oxygen, such as in manure. They can survive under adverse environmental conditions, especially $\mathrm{pH}$ range of 4 to 8 and temperature varying from 8 to $45^{\circ} \mathrm{C}$ (Leclerc et al., 1989). However, in this study, it seems that the composting conditions can be favourable for hygienization. Indeed, the high $\mathrm{pH}$ value, the temperature exceeding $45^{\circ} \mathrm{C}$ and the long composting time can eradicate this bacterium.

$E$ coli, one bacterium species of faecal coliform, is part of the normal flora of the intestinal tract of humans and animals. This microorganism can grow in adverse environments characterized by low $\mathrm{pH}$ and low temperatures. It can survive for long periods in soil and water. Besides, faecal coliforms may occur even after a long period of hygienization due to a cross contamination after compost preparation. Nevertheless, it was demonstrated that all microbial flora are inactivated within $24 \mathrm{~h}$ when the temperature reaches $50{ }^{\circ} \mathrm{C}$ during an aerobic thermophilic stabilization (Bicùdo and Goyal, 2003). Moreover, the effect of olive mill wastewater on soil microbial communities and especially the suppressiveness against the plant pathogen Rhizoctonia solani and possibly after root pathogenic fungi was demonstrated (Kotsou et al., 2004).

\subsection{Compost specifications}

The end products were characterized and their fertilizing potential value was assessed (Tab. III). The comparison of the main physico-chemical parameters of the prepared composts (windrows I and II) with the conventional cattle manure shows 
Table III. Physico-chemical specifications of stabilized composts and cattle manure. Compost I is the mature product of windrow I (75\% poultry manure and $25 \%$ exhausted olive cake); compost II is the mature product of windrow II (25\% poultry manure and $75 \%$ exhausted olive cake); OM: Organic matter; TOC: Total organic carbon, N.D.: Not determined.

\begin{tabular}{lccc}
\hline Properties & Compost I & Compost II & Cattle manure \\
\hline $\mathrm{pH}$ & $8.96 \pm 0.08$ & $8.63 \pm 0.11$ & $8.87 \pm 0.13$ \\
$\mathrm{EC}(\mathrm{mS} / \mathrm{cm})$ & $6.31 \pm 0.04$ & $5.46 \pm 0.11$ & $2.05 \pm 0.07$ \\
$\mathrm{C} / \mathrm{N}$ & $15.12 \pm 0.21$ & $16.85 \pm 0.38$ & $16.90 \pm 0.10$ \\
$\mathrm{Ash}(\%)$ & $46.60 \pm 0.36$ & $43.50 \pm 1.21$ & $30.44 \pm 0.71$ \\
$\mathrm{OM}(\%)$ & $53.40 \pm 0.36$ & $56.50 \pm 1.21$ & $69.56 \pm 0.71$ \\
$\mathrm{TOC}(\%)$ & $21.30 \pm 0.94$ & $23.43 \pm 0.28$ & $33.80 \pm 0.25$ \\
Total $\mathrm{N}(\%)$ & $1.403 \pm 0.042$ & $1.390 \pm 0.046$ & $1.998 \pm 0.063$ \\
$\mathrm{NH}_{4} \mathrm{~N}(\%)$ & $0.10 \pm 0.01$ & $0.08 \pm 0.01$ & $\mathrm{~N} . \mathrm{D}$. \\
$\mathrm{NO}_{3}-\mathrm{N}(\mathrm{ppm})$ & $35.000 \pm 0.985$ & $24.470 \pm 0.807$ & $\mathrm{~N} . \mathrm{D}$. \\
Phosphorus $(\mathrm{g} / \mathrm{kg})$ & $10.180 \pm 0.987$ & $5.256 \pm 0.588$ & $4.600 \pm 0.538$ \\
Potassium $(\mathrm{g} / \mathrm{kg})$ & $27.205 \pm 0.945$ & $22.093 \pm 0.423$ & $10.376 \pm 0.376$ \\
Calcium $(\mathrm{g} / \mathrm{kg})$ & $63.663 \pm 0.119$ & $39.000 \pm 0.050$ & $16.400 \pm 0.250$ \\
Magnesium $(\mathrm{g} / \mathrm{kg})$ & $5.248 \pm 0.007$ & $4.367 \pm 0.015$ & $3.800 \pm 0.044$ \\
Porosity $(\%)$ & $34.80 \pm 0.226$ & $35.20 \pm 0.333$ & $\mathrm{~N} . \mathrm{D}$. \\
\hline
\end{tabular}

globally interesting fertilizing values, yielded by the composts. According to French standards (NF U 44-051, 1981), specifying and defining organic conditioners, the prepared composts could be specified as vegetal composts since their total nitrogen expressed in percentage on a dry matter basis did not exceed $3 \%$, and their organic matter content over organic nitrogen was inferior to 55 .

The composition of minerals in each compost confirmed the beneficial effect of this organic fertilizer (Tab. III). Potassium content was high in this compost because of original provenance from poultry manure then the use of olive mill wastewater provided mineral and especially potassium and phosphor. Calcium concentration was very important in compost I, where poultry manure was predominant.

\subsection{Effects on soil fertilizing value}

\subsubsection{Agronomic performances}

The assessment of compost efficiency was performed on potato sown in the field. The potato stem growth in fields amended with each compost separately or with a combination of one compost with cattle manure did not exhibit any phototoxic effect. In Figure 5, the compost appeared to have a clear effect on growth than cattle manure. Nevertheless, the mixture of the latter with compost showed an improvement of stem growth compared to cattle manure used alone.

Moreover, the potato yield confirmed this positive effect of the different amendments used including the compost. Yet, the best yield resulted from compost I made of $75 \%$ poultry manure and $25 \%$ exhausted olive mill cake, used as the unique soil conditioner (Fig. 6). Berndt et al. (1996) reported the beneficial effect of spreading olive mill wastewater on agricultural soils. This application was demonstrated to provide an amount of fertilizer assessed at around 30 Tons/ha, without any soil polluting risk or phytotoxicity. The inequity of olive mill wastewater was hence confirmed (Ben Rouina et al., 1999; Zenjari and Nejmeddine,

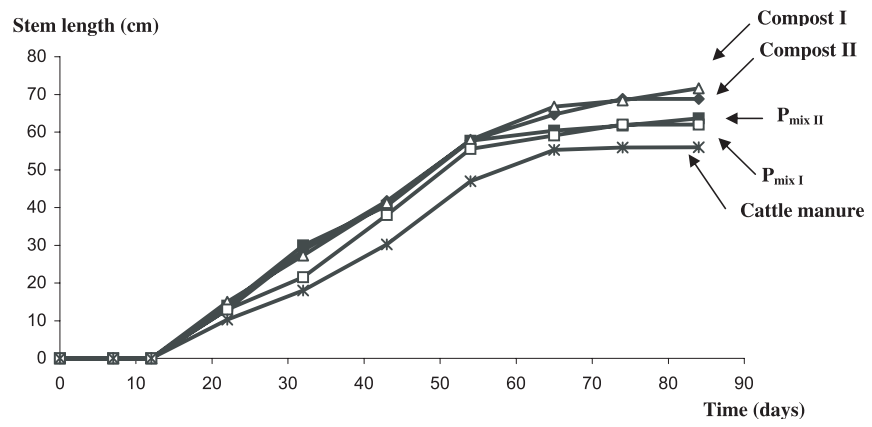

Figure 5. Stem length during potato growth in soils amended with mixtures of poultry manure and exhausted olive cake. Compost I: $75 \%$ poultry manure and $25 \%$ exhausted olive cake, and Compost II: $25 \%$ poultry manure and $75 \%$ exhausted olive cake; $\mathrm{P}_{\text {mix I }}: 75 \%$ compost I with $25 \%$ cattle manure; $\mathrm{P}_{\text {mix II: }}: 75 \%$ compost II with $25 \%$ cattle manure.

2001). Tomato et al. (1996) confirmed this finding by their experiments performed on both the crop-test and plant soil system progress in a field supplied with compost of olive mill wastewater at a rate equivalent to a manuring on the basis of organic matter. The tests were conducted on maize, horticultural plants and rye grass.

\subsubsection{Impact on the soil physico-chemical properties}

Among the most expected risks threatening soil fertility and resulting from olive mill wastewater use, $\mathrm{pH}$ and EC modifications are the most important ones (Zenjari and Nejmeddine, 2001). However, the use of this compost proved to be free of such risks. Indeed, as shown in Table IV, the use of these composts seemed to have no impact in terms of $\mathrm{pH}$ and $\mathrm{EC}$ when compared to cattle manure through different soil depths. 
Table IV. Physico-chemical parameters of different soil layers after amendment. EC: Electrical conductivity.

\begin{tabular}{lcccccccccccc}
\hline Parameters & \multicolumn{3}{c}{ Soil } & \multicolumn{4}{c}{ Soil + compost I } & \multicolumn{3}{c}{ Soil + compost II } & \multicolumn{3}{c}{ Soil + cattle manure } \\
\cline { 2 - 12 } & $0-15$ & $15-30$ & $30-50$ & $0-15$ & $15-30$ & $30-50$ & $0-15$ & $15-30$ & $30-50$ & $0-15$ & $15-30$ & $30-50$ \\
\hline pH & 8.80 & 8.87 & 9.04 & 8.54 & 8.59 & 8.56 & 8.63 & 8.67 & 8.56 & 8.47 & 8.48 & 8.50 \\
EC (mS/cm) & 0.26 & 0.25 & 0.20 & 0.35 & 0.31 & 0.29 & 0.34 & 0.28 & 0.27 & 0.40 & 0.35 & 0.30 \\
Phenols (\%) & 0.10 & 0.11 & 0.10 & 0.42 & 0.43 & 0.38 & 0.37 & 0.38 & 0.32 & 0.39 & 0.40 & 0.36 \\
\hline
\end{tabular}



Figure 6. Outputs of potato (Tons/ha) in soils amended with different kinds of fertilizer. Compost I: $75 \%$ poultry manure and $25 \%$ exhausted olive cake; Compost II: $25 \%$ poultry manure and $75 \%$ exhausted olive cake; $\mathrm{P}_{\text {mix I }}: 75 \%$ compost I with $25 \%$ cattle manure ; $\mathrm{P}_{\text {mix II }}: 75 \%$ compost II with $25 \%$ cattle manure.

\section{CONCLUSION}

The composting of poultry manure mixed with olive oil wastes was demonstrated to be an efficient way to provide fertilizer. Organic matter underwent an intensive biodegradation with an important thermophilic phase within 120 days. Microbiological analyses showed that the two composts were hygienized and compost I, having a higher rate of poultry manure, was characterized by its high concentration of thermophilic microorganisms, and its high activity during the composting process. This fact was confirmed by the kinetic parameters of organic matter biodegradation. The results showed that the humidification with olive mill wastewater improved the quality of the compost. The continuous use of olive mill wastewater did not have any negative impact on the process. The harmful phenolic compounds were widely decomposed during composting and the concentration of the minor remaining part would be degraded while applying the organic conditioner into the soil. The prepared composts were similar to an organic conditioner of vegetal compost. In terms of fertilizing value, the use of such composts including poultry manure and exhausted olive mill cake humidified with olive mill wastewater did not have any negative impact on soil phenols, $\mathrm{pH}$ and EC at different depths. The analyzed parameters were almost the same as those of the cattle manure. As a consequence, composting would be an efficient and suitable solution for polluting byproducts from agro-industries such as aviculture and oleiculture sectors.
Acknowledgments: The authors would like to acknowledge M. Ayadi Hajji from the National Engineering School in Sfax, for his help with English. Financial support from the Ministry of Higher Education, Scientific and Technological Research in Tunisia, through the premium for investment in researchdevelopment (PIRD-project, 2001), entitled "Valorisation agronomique et énergétique des grignons d'olives épuisés" is also gratefully acknowledged.

\section{REFERENCES}

Ammar E., Ben Rouina B. (1999) Potential horticultural utilization of olive oil processing wastewater, Acta Horto. 474, 741-744.

Association française de normalisation (1981) Amendements organiques : dénominations et spécifications (NF U 44-051), Ed. AFNOR, Paris, $6 \mathrm{p}$.

Association française de normalisation (1999) Recueil agroalimentaire. Microbiologie alimentaire. Tome 1. Méthodes horizontales. $7^{\mathrm{e}}$ ed., Paris, pp. 1-170; 209-214; 441-493; 543-569.

Ben Rouina B., Taamallah H., Ammar E. (1999) Vegetation water used as a fertilizer on young olive plants, Acta Horto. 474, 353-355.

Berndt L., Fiestas Ros de Ursinos J.A., Geissen K., Kachouri M., Klimm E., de Laborde de Monpezat G., Xanthoulis D. (1996) Les expériences méditerranéennes dans le traitement et l'élimination des eaux résiduaires des huileries d'olives, Deut. Gesellschaft Technische Zusammenarbeit, GTZ (Ed.), Tunis, pp. 89-114; 155-167.

Bessadok A. (2001) Les fientes de volailles de la nuisance à la valorisation, Bull. d'Information Avicole 23, 15-18.

Bicùdo J.R., Goyal S.M. (2003) Pathogens and manure management systems: a review, Environ. Technol. 24, 115-130.

Bouzouaia M., Rannen A. (2003) Les déjections avicoles, Bull. GIPA 23, $14-17$.

Chtourou M., Ammar E., Nasri M., Medhioub K. (2004) Isolation of a yeast. Trichosporon cutaneum, able to use low molecular weight phenolic compounds: application to olive mill waste water treatment, J. Chem. Technol. Biot. 79, 869-878.

Eklind Y., Kirchman H. (2000) Composting and storage of organic household waste with different litter amendments. II: nitrogen turnover and losses, Bioresource Technol. 74, 125-133.

Fang M., Wong J.W.C., Ma K.K., Wong H.A. (1999) Co-composting of sewage sludge and cool fly ash: nutrient transformations, Bioresource Technol. 67, 19-24.

Georgakakis D. (2000) Optimal use of the Hosoya system in composting poultry manure, Bioresource Technol. 72, 227-233.

Groupement Interprofessionnel de Production Avicole GIPA (2004) Le secteur avicole en Tunisie, GIPA (Ed.), Tunis, $18 \mathrm{p}$.

Houot S. (2000) Valorisation de composts en protection des cultures, TSM 10, 34-39.

Huang G.F., Fang M., Wu Q.T., Zhou L.X., Liao X.D., Wong J.W.C. (2001) Co-composting of pig manure with leaves, Environ. Technol. 22, 1203-1212. 
Kotsou M., Mari I., Lasaridi K., Chaptzipavlidis I., Balis C., Kiriacou A. (2004) The effect of olive mill wastewater (OMW) on soil microbial communities and suppressiveness against Rhizoctonia solani, Appl. Soil Ecol. 26, 113-121.

Leclerc H., Mossel D.A.A. (1989) Microbiologie du tube digestif, l'eau et les aliments, Doin (Ed.), Paris, pp. 205-255.

Mustin M. (1987) Le compost : gestion de la matière organique, Dubusc F. (Ed.), Paris, pp. 117-242.

Nicholson F.A., Chambers B.J., Smith K.A. (1996) Nutrient composition of poultry manures in England and Wales, Bioresource Technol. 58, 279-284.

Paredes C., Bernal M.P., Roig A., Cegarra J. (2001) Effects of olive mill wastewater addition in composting of agro-industrial and urban wastes, Biodegradation 12, 225-234.

Shabou R., Zairi M., Ben Dhia H. (2005) Characterization and environmental impacts of olive oil wastewater disposal, Environ. Technol. $26,35-45$.
Sierra J., Marti E., Montserrat G., Guanas R., Garau M. (2001) Characterization and evolution of a soil affected by olive oil mill wastewater disposal, Sci. Total Environ. 279, 107-214.

Tomato U., Galli E., Fiorelli F., Pasetti L. (1996) Fertilizers from composting of olive-oil mill wastewaters, Biodeterior. Biodegr. 38, $155-162$.

Vuorinen A.H. (2000) Effect of the bulking agent on acid and alkaline phosphomonoesterase and $\beta$-D-glucosidase activities during manure composting, Bioresource Technol. 75, 133-138.

Wong J.W.C., Ma Kh., Fang K.M., Cheung C. (1999) Utilization of a manure compost for organic farming in Hong Kong, Bioresource Technol. 67, 43-46.

Zenjari B., Nejmeddine A. (2001) Impact of spreading olive mill wastewater on soil characteristics: laboratory experiments, Agronomie 21, 749-755. 